DOI https://doi.org/10.30525/978-9934-26-073-5-2-30

\title{
НІМЕЦЬКІ СУБСТАНТИВНІ НЕОФРАЗЕОЛОГІЗМИ ЯК ПРОБЛЕМА ПЕРЕКЛАДУ УКРАЇНСЬКОЮ МОВОЮ
}

\author{
Любчук Н. В. \\ кандидат філологічних наук, доиент, \\ дочент кафедри германської філології та перекладу \\ Київського національного університету імені Тараса Шевченка \\ м. Київ, Украӥна
}

Фразеологізми належать до тих мовних одиниць, які чи не найвиразніше виражають оцінне ставлення до тих чи інших об'єктів, дій, подій. Через цю властивість вони досить часто були об'єктом дослідження. Проте мова не є статичною, вона постійно розвивається і збагачується новими словами і висловами, які активно використовуються в текстах різних жанрів. Потреба відтворювати неологізми, зокрема неофразеологізми, у перекладі спонукає до продовження розвідок в цій царині.

У 2007 році Д. Штеффенс описала принципи створення онлайнсловника німецьких неологізмів [1], а в 2015 р. вийшов друком словник «Neuer Wortschatz. Neologismen im Deutschen 2001-2010» [2, 3], в якому зібрано і описано лексичні і фразеологічні неологізми; одиниці, утворені після 2010 р. частково включені до онлайн-версії словника. Тут слід зазначити, що згідно з новітніми підходами в Німеччині до фразеологізмів відносять ідіоматичні, частково ідіоматичні та неідіоматичні усталені вислови, саме за цим принципом укладений згаданий словник $[2,3]$. В Україні віднесення неідіоматичних словосполук до фразеології часто ставиться під сумнів, тому під неофразеологізмом розуміємо ідіоматичний або частково ідіоматичний сталий вислів, що виник у певний відрізок розвитку мови, набув поширення і утвердився як загальноприйнята складова системи, феномен, новизна якого усвідомлюється носіями мови. Загалом за останні 20 років у німецькій мові утворилися 80 нових сталих висловів, 3 яких 32 ідіоматичних i 24 частково ідіоматичних. Особливістю німецьких неофразеологізмів $€$ наявність значної кількості субстантивних одиниць, що мають номінативний характер і служать для позначення різних об'єктів, явищ, характеристик, як от:

1. Реалії (напр., grünes Rezept);

2. Явища суспільного життя і побуту (напр., vertrauliche Geburt, Arabischer Frühling, blutige Entlassung); 
3. Професіні жаргонізми (напр., toxisches Papier, falsche Neun/ falscher Neuner);

4. Позначення поколінь (напр., Generation Silber, Generation Alpha, Generation Greta);

5. Оцінні характеристики (напр., ein gebrauchter Tag, großes Tennis, ein Elefant im Zimmer).

3 погляду складності для відтворення у перекладі ці одиниці можна розділити на інтернаціоналізми і локальні вислови, характерні лише для німецькомовного простору. Інтернаціоналізми наявні в багатьох мовах, тому, незважаючи на свою новизну, мають відповідники, хоча їхній компонентний склад може дещо відрізнятися (напр., Arabischer Frühling - арабська весна; alternativer Fakt - альтернативний факт; toxisches Papier - токсичні активи, токсичні иінні папери). Можливості відтворення реалій варіюються залежно від їх типу. Номінативні позначення, що не містять оцінного компонента, можна скалькувати за умови введення пояснення при першому згадуванні:

Gibt dir der Arzt ein grünes Rezept, kann es teuer werden [4]. - Якщчо лікар виписує зелений рецепт, ие може бути дорого («зелений рецепт» в Німеччині рекомендація, яку лікар виписує пачієнту, застрахованому в системі державного медичного страхування, для придбання ліків за власний рахунок).

Якщо номінативне позначення містить оцінний компонент, калькування може призвести до надмірного посилення експресивності 3 огляду на незвичність вислову. У випадку невідповідності ступеня експресивності забарвленню тексту в цілому доцільною видається заміна експресивного компонента на нейтральніший:

Von blutiger Entlassung sprechen Kritiker. Je früher die Kliniken die Patienten entlassen, desto mehr Kosten können sie sparen [5]. - Про дострокову виписку говорять критики. Чим раніше клініки виписують пацієнтів, тим більше коштів вони заощаджують.

Вислів blutige Entlassung означає виписку з лікарні 3 фінансових причин, хоча лікування після операції ще не завершено. В тексті, метою якого була ділова оцінка ситуації, дослівний переклад «кривава виписка» виглядав би недоречно.

Оцінні одиниці можуть бути відтворені за допомогою вільних словосполучень, експресивність при цьому дещо втрачається, проте оцінка зберігається (напр., ein gebrauchter Tag - невдалий день; großes Tennis - надзвичайна подія).

Один із зафіксованих висловів, ein Elefant im Zimmer (im Raum) (велика проблема, яку постійно ігнорують), виявився 
псевдоеквівалентом фразеологізму як слон у посудній крамнищі (wie ein Elefant im Porzellanladen). Такі одиниці належать до «фальшивих друзів» перекладача і потребують особливої уваги.

Окрему групу утворюють позначення поколінь, перше 3 яких з'явилося в 1951 році, наступні постійно утворюються за моделлю (Generation Silent (роки народження - 1928-1945); Generation (Baby) Boomer (1945-1964); Generation X (1965-1980); Generation $Y$ (= також Me або Millennials) (1981-1996); Generation $Z$ (= Zoomer) (1997-2009); Generation Alpha (3 2010) [6], Generation Silber (Generation 50 plus), Generation Praktikum, Generation Facebook, Generation G 8 (молоді люди, що закінчили восьмирічну гімназію), Generation Greta [7], Generation Lockdown [8]). Як видно з переліку, йдеться, з одного боку, про вікові групи з чітко визначеними роками народження, з іншого боку, про групи людей, яким притаманні певні характеристики. Якщо позначення поколінь за роком народження мають відповідники в українській мові: такі лексеми виникають в рамках теорії поколінь і досить швидко запозичуються з мови в мову (мовчазне покоління/ тихі, покоління Бебібумерів/ пророки, покоління X/ невідоме покоління/кочівники/ самостійні, покоління $\boldsymbol{Y}$ / Next/ міленіуми, покоління Z [9]), то нові, локальні одиниці і одиниці, що містять характеристики мають бути відтворені безпосередньо в тексті перекладу. 3 огляду на утворення таких висловів за моделлю найдоцільнішим способом відтворення видається калькування 3 введенням пояснення при першому згадуванні (напр., Generation Silber (Generation 50 plus) - покоління 50+, Generation Praktikum - покоління практикантів (молоді люди, які після закінчення (вищого) навчального закладу отримують від роботодавців лише пропозицію пройти практику або стажування замість постійного робочого місця), Generation Alpha покоління альфа, Generation Greta - покоління Грета (молоді люди, яких турбують зміни клімату), Generation Lockdown - покоління локдаун (молоді люди, початок трудової діяльності яких припадає на 2020 рік).

Підсумовуючи сказане, можна зауважити, що номінативний характер німецьких субстантивних неофразеологізмів зумовлює можливість відтворювати значну їх частину за допомогою калькування, що забезпечує збереження образності й оцінних конотацій; іншим способом перекладу $є$ заміна на вільні словосполучення, при цьому образність втрачається, оцінні конотації можуть бути збережені.

На часі видається укладення німецько-українського словника неологізмів, який став би в пригоді як перекладачам, так і всім, хто вивчає німецьку мову. 


\section{Література:}

1. Steffens D. Von «Aquajogging» bis «Zickenalarm». Neuer Wortschatz im Deutschen seit den 90-er Jahren im Spiegel des ersten größeren Neologismenwörterbuches. Der Sprachdienst. 2007. Jg. 51. № 4. S. 146-159.

2. Steffens D., al-Wadi D. Neuer Wortschatz. Neologismen im Deutschen 2001-2010. 3., durchgesehene Auflage Mannheim: Institut für Deutsche Sprache, 2015. Band 1: A-Kite. 316 c.

3. Steffens D., al-Wadi D. Neuer Wortschatz. Neologismen im Deutschen 2001-2010. 3., durchgesehene Auflage Mannheim: Institut für Deutsche Sprache, 2015. Band 2: kiten-Z. 324 c.

4. Grünes Rezept: So bekommst du dein Geld zurück. 15.08.2019. URL: https://www.jumpradio.de/thema/quicktipp/gruenes-rezept-100.html (дата звернення: 25.03.2021).

5. Anstatt geheilt «blutige Entlassung»? URL: https://www.swr.de/ betrifft/betrifft-krank-klinik-entlassung-gesund/-/id=98466/did=11588074/ nid=98466/19t6tjv/index.html (дата звернення: 25.03.2021).

6. Generation Silent, Baby Boomer, X, Y (Me, Millennials), Z oder Alpha. URL: https://www.adigiconsult.ch/glossar/generation-silentbaby-boomer-x-y-me-millennials-z-alpha/ (дата звернення: 25.03.2021).

7. Neologismenwörterbuch. Wörter unter Beobachtung https://www.owid.de/docs/neo/listen/monitor.jsp\# (дата звернення: 25.03.2021).

8. Loos M. Generation Lockdown: Wenn die Coronakrise den Berufsstart verpfuscht. 23.09.2020. URL: https://www.handelszeitung.ch/konjunktur/ generation-lockdown-wenn-die-coronakrise-den-berufsstart-verpfuscht (дата звернення: 25.03.2021).

9. Теорія поколінь. URL: https://www.bdut.org.ua/wp-content/uploads/ 2018/02/\%D1\%82\%D0\%B5\%D0\%BE\%D1\%80\%D1\%96\%D1\%8F-\%D0\% BF\%D0\%BE\%D0\%BA\%D0\%BE\%D0\%BB\%D1\%96\%D0\%BD\%D1\%8C.p df (дата звернення: 10.04.2021). 